In: Astrid Wonneberger, Mijal Gandelsman-Trier, Hauke Dorsch (eds.)

Migration - Networks - Skills. Anthropological Perspectives on

Mobility and Transformation. Bielefeld, transcript, 2016.

\title{
The Kashmiri Diaspora in Britain and the Limits of Political Mobilisation
}

MARTIN SÖKEFELD

\section{Introduction: The Problems of Diaspora}

The great euphoria about the diaspora concept ${ }^{1}$ is certainly over. ${ }^{2}$ While in the 1980s and especially the 1990s “diaspora” was eagerly adopted as an antidote against the "metaphysics of 'race', nation and bounded culture”, in Paul Gilroy's words (Gilroy 1997: 328), and experienced ever increasing popularity, the concept evoked more cautious and critical voices in the last decade. In the discourses of social sciences and cultural studies, “diaspora” has been mostly used as a term for a "social form" among the three meanings of the concept which Steve Vertovec (1997) identified. In fact, in many cases "diaspora” has been plainly employed as another term for (migrant) community. This usage of “diaspora” has

1 When I started to develop an interest in diaspora - at that time in the Alevi case Waltraud Kokot provided the intellectually stimulating environment at the Department of Social and Cultural Anthropology, Hamburg University, where I could pursue this interest. I am greatly indebted to Waltraud Kokot for her huge support.

2 Earlier versions of this paper were presented at the Universities of Stockholm, Oslo, Bielefeld, Tübingen and Zagreb. The discussions after these presentations helped very much to improve the paper. I would like to express my gratitude to the Wenner-Gren Foundation for Anthropological Research which generously funded fieldwork in Britain and in Azad Jammu and Kashmir. Fieldwork consisted of eight field trips to Britain between 2006 and 2010 of two to six weeks duration each. I worked mainly in Bradford, Greater Manchester, Birmingham and London with Kashmiri activists of secular-nationalist orientation. Around two months of research in Azad Kashmir and Pakistan took place mainly in 2007. 
been criticised and it has been argued that, instead of subverting, such a concept rather bolsters the "metaphysics" of nation, ethnic group and bounded culture (e.g. Anthias 1998, Soysal 2001). Brian Axel (2001) in particular pointed to the role of ideas of "origin" in this context. Especially the practice of tying diasporas to some place of origin (e.g. Safran 1991) - as in the usual practice of naming diasporas after a presumed provenance - strengthens the metaphysics of boundedness. Axel argued that diaspora should not be thought from some place of origin, but rather from the space in which it unfolds. Some diasporas, like the Sikhs who serve as Axel's example, create their particular "home" and "origin" from the diasporic vantage point, rather than carrying it already with them on their routes of migration. Accordingly, diaspora is not the result of some original or ongoing migration, but of a broader range of social and political processes.

The critique of essentialisation notwithstanding, diaspora very often continues to be treated as a social entity and a collective actor. A prominent example for this is Gabriel Sheffer's book Diaspora politics (Sheffer 2003). At first sight, Sheffer seems to avoid an essentialist conceptualisation of diaspora as an entity. He poses the question of how and why migrants form diasporas and thus goes beyond the simple assumption that diasporas are a direct outcome of migration. Yet once established, diasporas appear to be communities and collective actors who "do" something politically, who, for instance "extend support to beleaguered homelands and other diaspora communities of the same national origin" (p. 26). Significantly, Sheffer conceptualises diasporas in terms of maintenance of identities. Thus, diasporas continue because of their "members' wishes to maintain their ethno-national identities and contacts with their homeland and with other dispersed communities of the same ethnic origin" (ibid.). Sheffer acknowledges the role of diaspora organisations and also of the context of the "host country" in the constitution of diaspora. Still, according to him, all this only helps to actualise what essentially seems to be already there: "[...] a degree of cohesion emerges within those [migrant] groups. Again, solidarity and group cohesion are founded on the primordial, cultural and instrumental elements in their collective identities" (ibid., p. 80). Established on such "foundational" elements, diasporas are considered as acting collectively, in quite a similar way that we colloquially use to refer to the acts (or interests, experiences, etc.) of nations or states. In Sheffer's book phrases like "diasporas engage in” or "pursue” something abound; diasporas "achieve" their goals - or do not achieve them. I regard this way of talking about diaspora as inherently problematic. Although Sheffer does not consider diaspora explicitly as a simple outcome of migration, diaspora is viewed in terms of pre-existing phenomena. This is a very common approach which assesses diasporas in terms of continuity and change in comparison with 
the "home country”. Here, too, “origin” remains the constant reference and in spite of all changes something essential remains the same which, in the last instance, allows us to name a certain diaspora after its presumed “origin”. Elsewhere I have argued that such an approach is much too narrow and essentialising (Sökefeld 2004) and that diasporas cannot be meaningfully compared to some pristine state of origin before migration (which thereby becomes an entrenched "home”). Countering this approach I argued - following a social-constructionist approach to identity (e.g. Sökefeld 2008) - that identity is always imagined and practiced within a specific context, and that the imagination of a particular "identity of origin" (which itself needs to be contextualised) is only one factor among many that help to create particular discourses of identity. Thus, rather than taking for granted that a particular diaspora identity is "rooted" in a certain identity of origin, we need to consider why - if at all - the imagination of diasporic identity takes place in these particular terms. I suggested that the essentialisation of diaspora can be prevented by considering the formation of diaspora as a process of social and political mobilisation which can be analysed with concepts of social movement theory (Sökefeld 2006). Further, if diaspora is closely related to processes of mobilisation, diaspora can also be “de-mobilised” again. Diasporas may not only change but also fade away. In the rest of this article I will discuss such processes of mobilisation, taking the "Kashmiri diaspora" in the UK as an example.

\section{THE KASHMIRI DIASPORA IN THE UK}

This text is about "the Kashmiri diaspora" in the UK. My interest in the Kashmiri case was triggered by my earlier concern for the "political context of origin" $^{3}$ which includes the Kashmir dispute. ${ }^{4}$ Thus my "route" towards the Kashmiris in the UK followed the rather conventional, "rooted" approach which I criticised above. When I started to do research about Kashmiris in Britain I was strongly influenced by the publications of Nasreen Ali, Zafar Khan and Patricia Ellis who studied Kashmiris in Luton in the 1990s. Luton is a small town north

3 I resort to this phrase for the purpose of avoiding to essentialise by simply naming the origin. In the case of the Kashmiris this problem is particularly pertinent, as we will see, because their "context of origin" is highly disputed and fragmented.

4 I am highly interested in the Kashmir issue since I did fieldwork for my $\mathrm{PhD}$ thesis in Gilgit-Baltistan, the other part of erstwhile Jammu and Kashmir State that is under the control of Pakistan. See for instance Sökefeld 2005. 
of London with a large number of people originating from Kotli district in Azad Jammu and Kashmir (subsequently AJK). AJK, one of the two sections of erstwhile Jammu and Kashmir State (subsequently J\&K State) which since 1947 are under Pakistani control, is the area of origin of almost all Kashmiris in Britain. From the articles by Ali, Khan and Ellis an image of a politically very active and quite close-knit Kashmiri diaspora community emerged. A community which has influenced British foreign policy has engaged in local elections and has also exerted considerable influence in AJK (Ellis and Khan 1998, 1999a, 1999b, 2002). While Nasreen Ali argued more differentiated, pointing out, for instance, that there are different discourses of "Kashmiriness" which are authored by different kinds of actors (Ali 2002, 2003), the overall picture was that of diaspora as a collective political actor. While people of Kashmiri origin had been categorised as "Pakistanis" before, also in academic publications, ${ }^{5}$ because AJK is under Pakistani control, because they arrived on Pakistani passports and because Pakistan acts as "caretaker" for AJK, the authors argued that Kashmiris in Britain formed a separate ethnic/diasporic community and should be recognised as such. They emphasised that "migrants from Azad Kashmir and their offspring are identifying themselves first and foremost as Kashmiris" (Ali, Ellis and Khan 1996: 230), giving other possible identifications lesser salience, but also that in the 1990s this was a quite recent change. According to their diagnosis, the change was triggered mostly by developments in the Indian administered part of J\&K, namely the insurgency against Indian control which had started in 1989. They accorded a particularly significant role in this respect to the Jammu and Kashmir Liberation Front (JKLF), the secular-nationalist Kashmiri organisation which started the insurgency in Indian J\&K and which had originally been established in 1977 in Birmingham by political activists from AJK.

Having read these writings, I expected to find a vibrant Kashmiri diasporic community when I started fieldwork in Britain in 2006. As I was especially interested in politics, I worked mostly with activists of different parties and organisations. After more than four years of (intermittent) research, a different picture emerged. While for the political activists "Kashmiri" indeed is the first and foremost identification, this cannot be confirmed for the "community" at large. I encountered more failed projects than successful manifestations of the "Kashmiri diaspora". While the term "diaspora" has entered the political vocabulary of Kashmiri activists, a Kashmiri diaspora in the sense of a community which identifies itself primarily as Kashmiri has apparently largely vanished - if it ever existed. On the other hand, the history of Kashmiri mobilisation in Britain turned 
out to be much more complex. It cannot be reduced to the JKLF only. ${ }^{6}$ In this article I will outline a history of Kashmiri political mobilisation in Britain, considering first transnational politics, i.e. commitments that are related to issues in Kashmir, and then mobilisation related to British politics. After that I will dwell on failed Kashmiri projects. In the end I will offer some ideas towards a reconceptualisation of diaspora derived from the Kashmiri case.

\section{Kashmiri Mobilisation in Transnational Politics}

Individual migration from what later became AJK started already before the Subcontinent's partition and independence. ${ }^{7}$ From the 1950 s, chain migration developed, transferring large portions of the population of southern AJK (today's districts of Mirpur, Kotli and Bhimber), resulting in quite concentrated settlements of Kashmiris in Britain, especially in Birmingham, Bradford, different towns in Lancashire and around London. It is regularly estimated that 500,000 people of Kashmiri origin live in the UK (e.g. Ali 2003: 477). ${ }^{8}$ Sometimes even higher numbers are given. However, because "Kashmiri” is not a census category in the UK, there are no exact and reliable figures. This is an important issue of political mobilisation, as will be seen later.

Because there are close political relationships between AJK and Kashmiris in the UK, a few sentences about AJK politics are necessary in order to understand Kashmiri political mobilisation in Britain. ${ }^{9}$ The original idea of Azad Jammu and Kashmir was to create a democratic and independent J\&K State, free of the Maharaja's feudal rule. After the turmoil of partition and in the course of the dispute between India and Pakistan over the accession of the princely state of J\&K,

6 The JKLF itself is a very complex phenomenon. It has undergone a number of splits and mirrors the fragmentation of the "Kashmiri community".

7 The most detailed history of migration from AJK to the UK is given by Kalra 2000.

8 Ellis and Khan estimated 350,000 persons of Kashmiri background in 1999 (Ellis and Khan 1999b: 103). Muzamil Khan assumed in 2006 that there were 400,000 people from Mirpur alone in the UK (Khan 2006: 43).

9 By "Kashmiri political mobilisation" I mean all kinds of political activities that are related to ideas of Kashmir and Kashmiris (as state, nation, ethnic group, diaspora, etc.). There are other kinds of political activities by people who are categorised as "Kashmiri” which I do not include in this category, such as many fields of British home affairs but also politics of Islam. This distinction is necessary in order to de-essentialise "Kashmiris": Not everything "Kashmiris” do is "Kashmiri”. 
Azad ("Free") Jammu and Kashmir was declared on $4^{\text {th }}$ October 1947. There had been a brewing revolt against the Maharaja’s regime already since early 1947. In autumn of that year, "tribals” from Pakistan entered J\&K in order to support the uprising. Feeling strongly threatened, the Maharaja declared accession with India on October 26, 1947, to allow the entering of Indian troops into the State. Thus, the conflict was turned into a war between India and Pakistan. After the ceasefire of the first Kashmir war, AJK emerged as a small strip at the south-western edge of erstwhile J\&K State, separated from the Indian administered territory by the ceasefire line which was later renamed as Line of Control. Formally, AJK is a separate political body which today has a complete institutional setup including government, parliament and judiciary. De facto, however, AJK is almost completely dependent on and controlled by Pakistan. In fact, Pakistan is the only state which recognises AJK. For Pakistan, AJK serves as a kind of placeholder for the future accession of the whole J\&K which is envisioned and demanded by the country as solution of the Kashmir dispute. The close relationship with Pakistan dominates formal politics in AJK. For instance, candidates for the AJK legislative assembly are required to sign a declaration of loyalty with Pakistan saying that they desire and support the accession of J\&K with Pakistan.

Yet not all people in and from AJK were and are content with this state of affairs. The demand for independence of J\&K enjoys considerable support although it can hardly be freely articulated in AJK. A first milestone of political mobilisation in AJK against Pakistani control occurred in relation with the construction of the Mangla Dam in Mirpur between 1959 and 1967. When the large reservoir was flooded, an estimated number of 100,000 people were displaced by the rising water. Resistance against the construction of the dam in Mirpur was supported by Mirpuris, as migrants from AJK were called at that time, in Britain. The protest against the dam was ruthlessly suppressed by the AJK and the Pakistani governments. One outcome of the protest campaign was the establishment of a pro-independence party in AJK, the Jammu and Kashmir Plebiscite Front (PF), in 1965. The PF campaigned for the implementation of a referendum about the future of Jammu and Kashmir, as provisioned by the UN resolutions on Kashmir. Yet in contrast with these resolutions, the PF demanded three options for a plebiscite: beside accession with India or Pakistan also the independence of J\&K State. The PF had supporters among Kashmiris in Britain although there was hardly a formal party organisation in the UK. Yet, there was a potential for mobilisation: When in 1971, after the hijacking of an Indian aircraft from Srinagar to Lahore, large numbers of PF members and supporters were arrested in $\mathrm{Pa}$ kistan and AJK, sympathisers in Britain staged effective protests during visits of 
members of the Pakistani government, exerting pressure which contributed to the release of the prisoners. ${ }^{10}$

From the PF derives a first string of Kashmiri political mobilisation in Britain which can be termed secular-nationalist. After the hijacking the PF had rather difficult times in AJK due to close surveillance and pressure. As a consequence, the idea emerged to establish an organised and powerful branch in Britain. In 1975, two party leaders came to the UK and in early 1977 they established the Jammu and Kashmir Liberation Front (JKLF) in Birmingham as an overseas support organisation for the PF. Yet later the president of the JKLF, Amanullah Khan, took the organisation back to Azad Kashmir and turned it into a rival of the PF.

A second string of mobilisation can be termed leftist and internationalist. There was a small but very committed circle of Kashmiri activists in Britain who were influenced by the Palestinian struggle, the activism against the Vietnam War and other international issues. They conceived their activism in terms of anti-imperialism and anti-capitalism. John Hutnyk (2006) issued a very committed statement for the inclusion of leftist politics in the writings about British South Asians, and such leftist politics did indeed play an important role in Kashmiri activism. ${ }^{11}$ Leftist activists from Kashmir formed the United Kashmir Liberation Front (UKLF) in Birmingham in the early 1970s. The group joined the efforts of PF sympathisers in the aircraft hijacking case, although they did not share the overall aims of the PF, which they regarded as rather bourgeois. The UKLF cooperated with other leftists from South Asia like the Indian Workers' Association and the Pakistani Workers' Association. After a few years, the UKLF was turned into the Kashmiri Workers' Association (KWA). In contrast to the JKLF, the KWA developed strong links with British organisations like trade unions or antiracism initiatives. The KWA always remained a small group which nevertheless

10 The two hijackers from Indian administered J\&K had some relations with activists of the PF in AJK. When they arrived in Lahore, they were first welcomed as freedom fighters. At that time, Pakistan still consisted of a western and an eastern part (which became Bangladesh soon after), separated by the land mass of northern India. In consequence of the hijacking incident, India closed its airspace for Pakistani aircrafts. Transport between West- and East Pakistan was interrupted. After this, the Pakistani government blamed the hijackers as "Indian agents” and put them along with many PF activists to a special trial.

11 Leftist orientation among Kashmiris was not a product of the political context in Britain but played a role already in the political struggles of pre-1947 Jammu and Kashmir. 
introduced a number of significant and influential changes in Kashmiri politics in the UK. For instance, activists of the KWA started to call AJK "Pakistan Occupied Kashmir" (POK) in analogy with the term "Indian Occupied Kashmir" (IOK) which is generally used in Pakistan to refer to the territories administered by India. Also, the KWA started to use Pahari, the regional language of Mirpur, in its public meetings instead of Urdu, Pakistan's national language. The issue of language use is significant. "Mirpuris" were generally looked down upon by Pakistanis in Britain as kind of backward "hillbillies". Part of this negative stereotyping was their "Mirpuri" language which was considered as an unintelligible dialect of Punjabi and not as a language in its own right. Political activities of the KWA were clearly marked by opposition against Pakistani domination of AJK. Both the secular nationalists of PF and JKLF and the leftists of the KWA favoured the independence of Kashmir.

Both lines of mobilisation converged to some extent in 1984. At the beginning of this year, activists from around the JKLF kidnapped Ravinder Mhatre, an Indian diplomat in Birmingham, with the intention to force the release of Maqbool Bhat in India. Maqbool Bhat was a leader of the Jammu and Kashmir National Liberation Front (NLF), a militant wing of the PF, who was on the death row in India, having been convicted of the murder of an Indian policeman. The kidnappers did not achieve their goal. Ravinder Mhatre was killed and Maqbool Bhat executed in Delhi. The date of Bhat's execution, February 11, became subsequently a significant day of commemoration and mobilisation for Kashmiri activists, marked by public events all over Britain. In 1984, the murder of the Indian diplomat sparked large-scale police crackdowns on politically active Kashmiris in Britain. In this situation a leader of the JKLF called the KWA for assistance, although earlier there had been a lot of friction between both organisations. Now, the KWA mobilised its quite elaborate network of nonKashmiri, white British supporting organisations, mostly from the spectrum of campaigns against racism, framing the crackdown as a racist move.

After 1984 the JKLF was able to recruit many more members. Branches were established in almost thirty cities in the UK. Although the killing of Ravider Mhatre was generally condemned among Kashmiris, the events brought much publicity and with the execution of Maqbool Bhatt the JKLF had won a martyr who became a focal symbol of identification. Yet the JKLF became never as strong as it perhaps could have been because it was ridden with internal conflicts. Moreover, the alliance with others like the KWA did not last. Today, there are several different factions of the JKLF. From the early 1990s, it became obvious that the JKLF had collaborated with Pakistani intelligence agencies in triggering the insurgency in Indian administered J\&K. Some Kashmiri activists in 
Britain considered Pakistan simply as another occupying force in Kashmir and were very critical of such collaboration. Soon the JKLF became largely insignificant to the struggle in Indian Kashmir because the Pakistani agencies shifted their support to Islamist groups. The secular-nationalist uprising in Indian administered Kashmir largely turned out to be a failure (Sikand 2001). As a consequence, many Kashmiris in Britain became disillusioned with the JKLF.

\section{KashmiRIS IN BRITISH LOCAL POLITICS AND the Census Campaign}

From the late 1970s, people of AJK origin became involved in British local politics. In the British election system of strict majority vote minorities have much electoral weight. Being mostly labourers, the majority of people of Kashmiri background considered the Labour Party as their natural political representation. Increasingly, Kashmiris did not only vote for Labour candidates but demanded to stand for elections on Labour tickets themselves. One of the first Kashmiri councillors was Mohammad Ajeeb in Bradford, who in 1985 also became the first Lord Mayor of Kashmiri origin of a British city. British issues rather than anything connected with Kashmir were the most important reason to enter local politics. Mohammad Ajeeb's motivation was the struggle against racism, especially in the context of employment, which first triggered his commitment to anti-racist initiatives and trade unions and then brought him to the city council. The number of Kashmiri councillors grew in the 1980s and 1990s. While for many the experience of discrimination had already been the reason to enter local politics, the difficult social situation of Asian immigrants became even more apparent through their involvement in the councils which gave access to social monitoring data. There was a perception that people of Kashmiri background were actually worse off in terms of housing, education, employment, etc. than other Asians, Pakistanis included. Statistically, however, Kashmiris remained invisible because statistics categorised Asians according to their nation-states of origin. Having no nation-state of their own, people from AJK were merged with Pakistanis. On the basis of circumstantial evidence Kashmiri councillors and activists presumed that Pakistanis were actually much better off than Kashmiris and that the data actually provided a wrong image of the Kashmiris' social situation.

According to the narrative of Kashmiri activists, Kashmiris in Britain were dominated by Pakistanis although there were presumably many more Kashmiris than Pakistanis in the UK. Being better educated and connected with British mainstream-society than Kashmiris Pakistanis acted as their representatives in 
British institutionalised multiculturalism without, however, caring for the needs of the Kashmiris. Here, too, the issue of language was significant. In the UK, immigrants are entitled to interpreting services, for instance when admitted to hospital. The interpreting business was dominated by Pakistanis, too. They offered English-Urdu interpretation which was of little use for many Kashmiris who did not know Urdu but spoke Pahari. In the 1990s, Kashmiri activists started to lobby British institutions for the need to recognise Pahari as a separate language and for Pahari language services. This meant, in fact, the recognition of Kashmiris as a separate ethnic group, distinct from Pakistanis.

In a kind of surprise move, some Kashmiri councillors and activists achieved the recognition of Kashmiris by the Bradford City Council in late 1998. Pakistanis and pro-Pakistani Kashmiris unsuccessfully attempted to reverse the decision. To the contrary, more and more British towns and cities with a significant population of Kashmiri background followed the example of Bradford and recognised Kashmiris as a separate ethnic group. In monitoring of council employment, housing and other issues of local administration Kashmiris became visible. Nothing changed, however, in nationally governed policy fields such as education and health. Soon after their recognition in Bradford, Kashmiri activists came together and started a campaign for the recognition of Kashmiris on a national level. This was the Kashmiri National Identity Campaign (KNIC). Many of these activists were supporters of the independence of J\&K State and were closely related to groups like JKLF or KWA. Nasreen Ali (2003) therefore discusses the KNIC in terms of the Kashmiri nation. This was, however, not the only possible reference. I asked KNIC activists whether the word national in the campaign's name referred to the Kashmiri nation or to the British national level. My interlocutors told me that the reference to the "national" was deliberately left open and vague. The intention of this ambiguity was to avoid the campaign being drawn into the antinomies of Kashmiri politics and not to alienate people of Kashmiri background who hesitated to support the demand for independence of J\&K State.

The KNIC's purpose was to make "Kashmiri" a category of the British census. The census is taken every ten years and the next one was due in 2001. Since 1991, the census asked for the ethnic self-categorisation. ${ }^{12}$ For persons of South Asian background, "ethnicity" was again categorised in terms of the nation-state of origin. Thus, respondents could tick an "Indian" or "Bangladeshi" box but there was no "Kashmiri" box. The KNIC demanded the addition of a "Kashmiri" tick-box in the 2001 census forms. The Office of National Statistics (ONS)

12 On the inclusion of ethnic categories in the census see Ballard 1996. 
which carries out the census responded, however, that it was impossible to change the questionnaire at a rather short notice. The only option for respondents to get Kashmiri ethnicity counted was to tick the box "other ethnic group" and then to write "Kashmiri" in the blank space provided beneath. The KNIC attempted to publicise this possibility. The Campaign distributed flyers with titles like Kashmiris in Britain - no longer invisible or Be Kashmiri - be counted. Through a newsletter published in 2001 people were asked to tick the box "other" and fill in Kashmiri. The importance of the getting Kashmiri ethnicity counted was explained as follows:

- Kashmiris will be recognised in their own right as equally as any other community and not be labelled as Indians or Pakistanis depending on which part of divided Kashmir they come from.

- Kashmiris will be able to promote their rich culture, customs and national interests.

- Local and national institutions will be able to take into account and reflect the Kashmiri aspirations and needs in provisions and delivery of services.

- Government policies will have to recognise and reflect the large Kashmiri presence in this country (KNIC Newsletter, issue 1, 2001).

The campaign was opposed by pro-Pakistani Kashmiris, including the UK branch of the Jammu and Kashmir Muslim Conference, the dominant proPakistani party in AJK, and by British Pakistanis. It was argued that the campaign divided the "Pakistani community" in Britain. In order to publicise the call to get counted, the KNIC intended to publish an advertisement in the leading Urdu daily in the UK, Jang, which is a branch of the largest-selling Pakistani Urdu daily newspaper. But Jang refused to print the advert. In effect, no means for the wider circulation of the call were available.

The campaign largely failed. Little more than 22,000 persons identified themselves as ethnic Kashmiris in the census. This was much less than had been expected. The number is actually negligible compared to the estimated number of 500,000 Kashmiris living in the UK which is regularly quoted by Kashmiri activists. After this failure, the campaign became dormant. The issue, however, remained pressing for some of the activists. One diagnosis of the failure was that it was due to the lack of publicity and media coverage.

As a consequence, a group of Kashmiris who had been at the forefront of the KNIC and who had earlier been related also to the KWA, the JKLF and other groups established a Kashmiri satellite TV channel in 2006. The idea of the Bradford-based channel was to give Kashmiris their own media voice. The 
channel was appropriately called Aapna Channel (literally: Own channel). With another studio in AJK and correspondents in Indian J\&K the intention was to create a transnational Kashmiri public sphere. In terms of response to call-in programmes and messages from the viewers the response of the British Kashmiri public to the channel was quite enthusiastic. Without well-heeded investors and sponsors, however, the channel had from the beginning financial problems. In AJK, the programme had to be very balanced politically. After just a few days of regular transmission, the channel was taken out of the local cable network distribution by the government of AJK because it had aired some critical news item. Only after much negotiation the programme could start again in Mirpur.

After one and a half year in operation, the channel went bankrupt. It was replaced by another channel called Kashmir Broadcasting Corporation (KBC), based in Manchester and run by largely the same people. Yet KBC, too, broadcast for one year only. Thus, a Kashmiri voice in the media was lacking again.

This was regarded with particular regret when, in view of the next census due in 2011, efforts to revive the KNIC were started in 2008. The main actor of the KNIC was now Daalat Ali, a long time Kashmiri activist of the Manchester area. Daalat Ali had already coordinated the pre-2001 campaign for some time. Now, however, it was much more difficult to muster support which was more than nominal. While non-Kashmiri organisations like some church groups supported the Kashmiri claim for national recognition, as did an Early Day Motion in the British Parliament, ${ }^{13}$ less Kashmiris were ready to commit themselves to the campaign than ten years earlier. It was not possible to build a similarly strong and extensive network. The campaign took more to writing letters to the ONS than attempting to create public awareness and pressure. Already in autumn 2009 the ONS made clear that there would be no "Kashmiri tick-box" in the cen-

13 Early Day Motion 1268, initiated by Member of Parliament Linda Riordan and signed by 54 MPs in total. The Motion stated: "That this House recognises there is a considerable Kashmir community within the UK and praises the community for its contribution to the fabric of British life; notes that in previous census returns there has not been a separate Kashmiri ethnic group category; therefore calls on the Government to give recognition to the 600,000 Kashmiri people estimated to be living in the UK by ensuring that the 2011 census return has a separate section for Kashmiri people to identify themselves; and looks forward to Kashmiri people living in the UK being able to register their identity as the many other ethnic groups that live in the UK are able to do.” Available online: http://edmi.parliament.uk/EDMi/EDMDetails.aspx?EDMID= 35502 (13 October 2010). Early Day Motions are, however, a rather symbolical element of British parliamentary culture which does not carry much actual weight. 
sus questionnaire for 2011. The ONS argued that existing data did not sufficiently support the need for a separate tick-box. As many more groups demanded to be included in the census, there would be additional tick-boxes for "Gypsy or Irish Traveller” and for "Arab”, but not for Kashmiris. According to the ONS there was not sufficient space in the questionnaire for further ethnic tick-boxes.

This announcement aroused much protest. After negotiations, the ONS finally agreed to carry out a "Kashmiri Research Project" on the census question. Two versions of the census forms were randomly mailed out to 27,000 households in urban areas where a high percentage of "Pakistani” population had been recorded by the census of 2001. Half of the forms contained the "Kashmiri" tickbox while the rest had the "other" tick-box only. The idea was to see whether the presence of the "Kashmiri" tick-box in the form would produce a significant different response in self-identification.

The inclusion of the tick-box had indeed a significant effect: More than four times as many respondents identified themselves as "Kashmiri" compared to those who had received a questionnaire with the "other" and write-in option only. With the tick-box, the Pakistani-Kashmiri-ratio decreased from 21.5:1 to 3.7:1 (see table).

Table 1: Ratios of Pakistanis to Kashmiris in the postal test survey "Kashmiri Postal Test areas” (source: ONS 2009. Kashmiri Research Project, p. 16)

\begin{tabular}{|l|c|c|}
\hline & $\begin{array}{c}\text { Question without } \\
\text { Kashmiri tick-box } \\
\text { (4,944 people) }\end{array}$ & $\begin{array}{c}\text { Question with } \\
\text { Kashmiri tick-box } \\
\mathbf{( 4 , 7 8 4} \text { people) }\end{array}$ \\
\hline $\begin{array}{l}\text { Per cent of people ticking } \\
\text { Pakistani }\end{array}$ & 40.8 & 30.8 \\
\hline $\begin{array}{l}\text { Per cent of people ticking or } \\
\text { writing in Kashmiri }\end{array}$ & 1.9 & 8.4 \\
\hline Ratio (Pakistani to Kashmiri) & $21.5: 1$ & $3.7: 1$ \\
\hline
\end{tabular}

Still, the results also show that either there are many more Pakistanis than Kashmiris (which according to other evidence is highly improbable) or that many, if not most people from AJK continue to identify themselves as Pakistanis, even if they are offered explicit identification as Kashmiris. Analysis of the further information elicited showed that there was no significant difference regarding indicators like qualification, employment, health, etc. between those who ticked "Kashmiri" and those who self-identified as "Pakistani". The ONS concluded that the argument of the KNIC that Kashmiris are more disadvantaged than Pakistanis and that therefore social services need to be monitored ethnically 
was not valid and that accordingly the differentiation of Pakistanis and Kashmiris in the census form was unnecessary. Commenting on this argument Daalat Ali told me that Kashmiris were effectively compared with Kashmiris (who identified as Pakistanis) and that therefore effective information on social differences was still lacking. Yet also further lobbying did not help. The 2011 Census was carried out without the Kashmiri tick-box and only 25,335 persons identified themselves as Kashmiri. ${ }^{14}$

In the failed campaign, organisations like the JKLF - or similar groups, for that matter - did not provide much public support. They had largely lost the power to mobilise people. In February 11, 2009, on the anniversary of Maqbool Bhat's execution, I witnessed a demonstration of one JKLF faction in front of the Indian High Commission in London. The organisation had called for the demonstration in order to demand the relocation of Maqbool Bhat's remains from an unmarked grave in Tihar Jail in Delhi to the Martyrs' Graveyard in Srinagar, Kashmir. Less than thirty persons followed the call. In the traffic mayhem of central London the protestors were hardly discernible.

\section{A KASHMIRI DIASPORA IN THE UK?}

Considering all this, what can be said about the "Kashmiri diaspora” in Britain? The present scene contrasts starkly with the image drawn by Ali, Ellis and Khan in their various articles published a decade or more ago. There are activists who use the concept Kashmiri diaspora and presuppose that there is a Kashmiri diaspora community, even if only a minority of people of Kashmiri background in the UK identify themselves (primarily?) as Kashmiris. Yet this "Kashmiri diaspora” is much more a political project than a descriptive category of a social community.

The Kashmiri case is quite complex. It supports Brian Axel's warning against conceiving of a diaspora in the first place by linking it to some place of origin. "Place of origin" or "home" are very complicated notions in the case of Kashmiris. Their "place of origin" is a fragment of a territory that is bitterly disputed in a postcolonial struggle between two much larger powers. Already the idea what this "home" is or should be is utterly disputed: Is it a future part of Pakistan, conceived as the nation-state and "home" of Muslims in South Asia? Or is it a territory and nation under occupation that needs to be liberated from both

14 See 2011 Census: Table CT0010 Ethnic group (write-in responses), available online at http://www.ons.gov.uk/ons/index.html (accessed May 24, 2013). 
India and Pakistan? Political opportunities in Pakistan as well as in AJK are inimical to the latter stance. The goal of Kashmiri independence cannot be voiced freely and its adherents are strictly excluded from formal political opportunities in AJK. In Britain, however, the mobilisation of a Kashmiri diaspora around the goal of Kashmiri independence is possible, but also contested. It has to contest political perspectives which regard Kashmir as a rightful part of Pakistan. Among people of AJK origin in the UK, the goal of ilhaq-e-Pakistan (the merger with Pakistan) is not totally dismissed. Pro-Pakistani Kashmiri parties like the Muslim Conference have their branches and activities in Britain, too. In contrast to the strict opposition in the past, however, Muslim Conference activists, in spite of their Pakistan-orientation, nowadays sometimes support the recognition of Kashmiris as a separate group in Britain.

Yet political commitments of Kashmiris in the UK are not limited to what may be called "home-issues". The British multiculturalist system with its concept of community provides political opportunities for Kashmiris. In the UK, multiculturalism is largely organised and institutionalised at the municipal level. In many cases, local authorities assumed a corporate unity among ethnic minorities and dealt with them through "community leaders" who were themselves interested in conveying an image of unity of the section of the population which they claimed to represent (Vertovec 1996). ${ }^{15}$ This way, multiculturalism came to “convey a picture of society as a 'mosaic' of several bounded, nameable, individually homogeneous and unmeltable minority uni-cultures” (Vertovec 1996: 51) which are referred to as "communities". ${ }^{16}$ The statistical monitoring of "communities” at municipal level enables the formal recognition of a group, as has been achieved by Kashmiris in many places. So far, however, this recognition is restricted to municipal affairs only and could not be extended to the national level.

Because migrants from Azad Kashmir have settled in a concentrated manner in certain towns and cities and because of the British election system Kashmiris wield considerable electoral power in these places. There are many Kashmiri city councillors now and there is considerable competition for council seats. Yet the strong participation in elections engenders a certain fragmentation of the "community" along political lines. Fragmentation is augmented by the continuing importance of biraderis. Biraderis are kinship networks based on the norm

15 See Werbner 1991 for the analysis of such "community” politics in Manchester.

16 Knott (2009) details how British Hindus became a "faith community" largely in response to official "community discourse". 
of reciprocity. ${ }^{17}$ The two dominant, rivalling biraderis of people from AJK in Britain are Jats and Rajas. Biraderis play an important role among British Kashmiris, also in elections, because they are essential for the mobilisation of support and votes. ${ }^{18}$ There is neither an overarching organisational framework that binds Kashmiris together as Kashmiris, nor a shared pattern of identity practices or events which could overcome this fragmentation.

If we accept that there was a vibrant Kashmiri diaspora community in the 1990s as described by Ali, Ellis and Khan, the question arises what changes have occurred since that time. I see basically three points. First, Ellis and Khan have emphasised the role of the insurgency in Indian J\&K against Indian rule. After the initial phase of strong popular mobilisation, which was mirrored among UK Kashmiris, the insurgency led to a long-lasting and brutal war between militant Islamist groups and Indian state forces. Diasporic support for the struggle dwindled and fragmented. This is embodied in the fragmentation of the JKLF ${ }^{19}$ into various factions, which often charge each other of being Indian or Pakistani agents. Although Indian forces continue their very repressive regime in Jammu and Kashmir (Duschinsky 2009, 2010), there is very little commotion among British Kashmiris in terms of public protest against the atrocities and solidarity with the victims. "Home issues" that arouse action among British Kashmiris, like elections, for instance, are mostly limited to issues in AJK. ${ }^{20}$ It seems that in terms of practical action and commitment the idea of a Kashmiri nation which includes the whole of the former princely state does not carry very far today. ${ }^{21}$

Secondly, in consequence of the ongoing "war against terror" there is a strong inclination, especially among the younger generation of Kashmiri origin,

17 Biraderi is a quite complex and ambiguous concept the discussion of which goes much beyond the scope of this paper. See Alavi 1972, Ahmad 1977.

18 For biraderi and politics among British Pakistanis see Akhtar 2013 and Werbner 1989 who writes about zat which is largely a synonym of biraderi.

19 Pat Ellis and Zafar Khan's emphasis of the role of the JKLF may in part also be triggered by the fact that Zafar Khan continues to be an important activist of one of the party's factions.

20 More precisely, they are mostly limited to the migrants' areas of origin in southern AJK. Until recently, British Kashmiris from Mirpur cared little for what happened in AJK's capital Muzaffarabad, for instance. This changed to some extent through the devastating earthquake of 2005 which was followed by strong transnational efforts to provide relief (Rehman and Kalra 2006).

21 This is reciprocated by Valley Kashmiris from the Indian side for most of whom people from Mirpur are at best seen as being very marginally “Kashmiri”, if at all. 
to disregard the more parochial and particularistic identification with a "Kashmiri nation” in favour of the much more universal identification as Muslims (Sökefeld and Bolognani 2011). In the years since I started research, public space in the urban areas with considerable Kashmiri/Pakistani population has been strongly Islamised, in terms of Islamic banking, Islamic bookshops, clothing and the like. There is a strong appeal to Muslim solidarity and a feeling that Muslims are globally pressurised and put into danger. Young Kashmiris easily take out demonstrations against the war in Gaza and for the liberation of Palestine, but at present cannot be mobilised to the same extent for any issue relating to Kashmir. Kashmiri independence politics have mostly had a very secularist orientation (Sökefeld 2012) which apparently has less appeal today.

Kashmiri activists formulate a third, interrelated point: There is a lack of "Kashmiri consciousness", especially among the younger generation. Daalat Ali, for instance, laments that whenever "home countries" become a topic in English schools, young Kashmiris learn about Pakistan and not about Kashmir. According to his diagnosis, British multicultural education neglects and obscures Kashmiri history and culture - another consequence of the non-recognition of Kashmiris at the British national level. This lack is not balanced by a strong transmission of Kashmiri culture and "consciousness" within the families. Indeed, "being Kashmiri” is mostly a domain of middle-aged and older males. Young people and women of all ages were conspicuously absent from the public meetings on Kashmiri issues which I attended during my research.

Thus, although there is at present hardly a Kashmiri diaspora community in Britain in the strong and conventional sense of the concept "community” which implies unity, closeness and homogeneity and - since Ferdinand Tönnies (1887) contrasted "community” with "society" - largely conveys ideas of "interpersonal warmth, shared interests, and loyalty” (Baumann 1996: 15) ${ }^{22}$ there are (male) activists who still struggle for the formation and mobilisation of such a community; activists who attempt to mobilise people from Kashmir to self-identify as Kashmiris and who in their efforts already presuppose the Kashmiri community. The Kashmiri diaspora is a kind of community in the making. It is basically a discourse produced and sustained by diaspora activists, combined with certain (political) practices that intend the institutionalisation of a community.

Putting the Kashmiri diaspora into question does not mean to negate transnational relations between people from AJK in the UK and people in AJK. It asks, however, whether these relations are framed by actors, explicitly or implicitly, as

22 For critical views on community see Cohen 1985, Alleyne 2002, Amit 2002, Amit and Rapport 2002. 
relations among Kashmiris. My emphasis that there is no Kashmiri diaspora community in the strong sense of the term does not mean that there are no diasporic or transnational relations and commitments by the people that are categorised as "Kashmiri" by Kashmiri activists. There are plenty of such relations and commitments in many areas of their lives. Yet these are not necessarily transnational relations as Kashmiris, but, perhaps, as Pakistanis, as Mirpuris, as people from Dodiyal or Chakswari village, as Jats or as Rajas, as Muslims, as followers of the Jammu and Kashmir Muslim Conference or some other party, or simply as aapne ("our own"). All these relations produce different social groupings which do not conflate in an overarching, inclusive "Kashmiri community". The distinction of these diverse diasporic and transnational commitments may perhaps seem trivial or pedantic, at first sight. Yet it is not. Only the distinction between different lines of relationships and commitments enables us to avoid an essentialist conception of diaspora that simply presupposes what needs to be ascertained. It enables us not to simply equate activist discourse with social scientific analysis.

The presence of people from AK in Britain is not a sufficient condition for a Kashmiri diaspora. In order to establish such a diaspora successful processes of mobilisation are required. Although diaspora is mostly theorised in terms of movements and relations across borders, mobilising diaspora implies the construction of boundaries which circumscribe the intended "community". While case studies of diaspora and diaspora theory have mostly focused on the boundary between the immigrant and the native, non-migrant population, ${ }^{23}$ the Kashmiri case shows that boundaries between different migrant groups may have a particular significance for the construction of diaspora. ${ }^{24}$ What is emphasised by Kashmiri activists in the UK is the difference and boundary between Kashmiris and Pakistanis, not the difference between Kashmiris and native "white" British. Significantly, however, this endeavour of boundary-making takes place in an institutional arena which is provided by the "host" society. The strategy is to demand the recognition of the boundary and the difference between Kashmiris and Pakistani by the British institutional structure and not to directly address a Pakistani community in the UK.

23 Cf. the well-known definition of "diaspora” by William Safran (1991).

24 This is also true for the Alevi case which I studied earlier (Sökefeld 2008). Alevis in Germany in the first place point out their difference from Sunni Turkish immigrants and emphasise their compatibility with the native German population. For a comparison of Alevis and Kashmiris see Sökefeld 2014. 


\section{Conceptualising Diaspora}

Focusing on the Kashmiri case, I have outlined an example of a history of mobilising diaspora. Mobilisation has remained limited so far. There is a considerable and apparently growing gap between the actual level of mobilisation and the diaspora community that is imagined, invoked and claimed by its activists. There is no diaspora in the sense of a unified community, an entity, a collective actor. Rather, there are claims for and discourses about community (and, significantly, its others). Further, there is a great variety of actors, some of whom organise collectively to a certain extent, who establish and keep moving a web of crisscrossing, sometimes overlapping and often contradicting activities. What light does the Kashmiri example throw on the conceptualisation of diaspora?

First, when we consider processes of social and political mobilisation as a necessary condition for diaspora, we have to take into account that mobilisation may not only grow but also wane, and, in the last instance, even fail and disappear. Diaspora may be mobilised, but also “de-mobilised” again. Thus, what was a thriving, self-conscious community more than a decade ago may today appear as a rather forlorn imagination of a few remaining activists. Like other social forms, diaspora is not forever. It is dynamic also in the sense that it may expire.

Second, from an analytical point of view the conventional conceptual twinning of "diaspora” and "community" is highly problematic. It is very prone to simply replicating actors’ emic essentialist concepts and perspectives. As I have pointed out for the Kashmiri example, although there is hardly a clear-cut, unambiguously outlined diaspora community, there is a multitude of diverse transnational, diasporic relationships which are sustained and reproduced by people of Kashmiri background. In order to overcome essentialist notions of "community" the metaphor of a cloud may help to conceptualise diaspora: What we find is “clouds" of dynamic and changing transnational, diasporic relationships which partly overlap but sometimes separate, which may concentrate and condense at one point but dissolve and vanish at another time.

Like other social concepts, the concept of diaspora is intended to create order in an increasingly complex world. It is used to sort people according to their "origins", in most cases, and thereby puts those who are apparently out of place back into a place. In his book Organizing Modernity, John Law, following Zygmunt Bauman (1991), has referred to (social) order as "the dream, or the nightmare, of modernity” (Law 1994: 2). Law points out that order is, luckily perhaps, never fully achieved: "Perhaps there is ordering, but there is certainly no order [...] Instead there are more or less precarious and partial accomplishments that 
may be overturned”, he writes (p. 1f.). John Law turns order into ordering, the noun into a verb and the intended product into a process.

Ordering works through the basic twin operations of exclusion and inclusion that attempt to determine who belongs to which category (and in which way) and who does not. Yet ultimately, neither inclusion nor exclusion fully achieves its goal. There are competing ways of ordering. People sometimes resist being excluded or included; but sometimes they also do not care. Many “cases” simply remain ambivalent. Order is always threatened and challenged by a kind of social entropy. Order, a neat categorisation of people, is never totally achieved.

In this sense, diaspora can be considered as an ordering concept. It is used to categorise people and to claim or to negate relationships of belonging. It is used as such by actors, whether they belong to the claimed diaspora category or not, and by social scientists as observers. If we conceive of diaspora as concept of ordering (which never, finally, achieves order), we cannot regard diaspora as an entity. Instead, diaspora should be viewed as a process. Diaspora is not a community, except we consider community as a process, too - a social process of attempting to recruit people and to exclude others, of struggling to disseminate certain ideas of belonging in the place of others, a process of drawing and challenging boundaries. Community, like diaspora, is essentially a process of mobilisation. Mobilisation may be "hotter" or "cooler", depending, for instance, on how disputed it is, or on the extent to which mobilisation congeals into institutions. Yet like diaspora, community as an entity is never finally achieved.

\section{REFERENCES}

Ahmad, Saghir (1977) Class and Power in a Punjabi Village. New York: Monthly Review Press.

Akhtar, Parveen (2013) British Muslim Politics: Examining Pakistani biraderi networks. Basingstoke: Palgrave Macmillan.

Alavi, Hamza (1972) "Kinship in West Punjab Villages.” Contributions to Indian Sociology 6: pp. 1-27.

Ali, Nasreen (2002) Kashmiri nationalism beyond the nation-state. South Asia Research 22: pp. 145-160

- (2003) Diaspora and nation: Displacement and the politics of Kashmiri identity in Britain. Contemporary South Asia 12: pp. 471-480.

Ali, Nasreen, Patricia Ellis and Zafar Khan (1996) The 1990s: A time to separate British Punjabi and British Kashmiri identity. In: Singh, Gurharpal and Ian 
Talbot (eds.): Punjabi identity: continuity and change. Delhi: Manohar: pp. 229-256.

Alleyne, Brian (2002) An idea of community and its discontents: towards a more reflexive sense of belonging in multicultural Britain. Ethnic and Racial Studies 25: pp. 607-627.

Amit, Vered (ed.) (2002) Realizing community: Concepts, social relationships and sentiments. London and New York: Routledge.

Amit, Vered and Nigel Rapport (2002) The trouble with community: Anthropological reflections on movement, identity and collectivity. London: Pluto Press.

Anthias, Floya (1998) Evaluating “diaspora”: Beyond ethnicity? Sociology 32: pp. 557-80.

Anwar, Muhammad (1979) The myth of return: Pakistanis in Britain. London: Heinemann.

Axel, Brian Keith (2001) The nation's tortured body: Violence, representation and the formation of a Sikh “diaspora”. Durham: Duke University Press.

Ballard, Roger (1983) Emigration in a Wider Context: Jullundur and Mirpur Compared. New Community 11: pp. 117-136.

- (1996) Negotiating race and ethnicity: exploring the implications of the 1991 Census. Patterns of Prejudice 30 (3): pp. 3-33.

Baumann, Gerd (1996) Contesting culture: discourses of identity in multi-ethnic London and Cambridge: Cambridge University Press.

Bauman, Zygmunt (1991) Modernity and ambivalence. Ithaca: Cornell University Press.

Bolognani, Marta (2007) The myth of return: Dismissal, survival or revival? A Bradford example of transnationalism as a political instrument. Journal of Ethnic and Migration Studies 33: pp. 59-76.

Brubaker, Rogers (2005) The “diaspora” diaspora. Ethnic and Racial Studies 28: pp. 1-19.

Cohen, Anthony P. (1985) The symbolic construction of community. London: Routledge.

Duschinski, Haley (2009) Destiny effects: Militarization, state power, and punitive containment in Kashmir Valley. Anthropological Quarterly 82: pp. 691718.

- (2010) Reproducing regimes of impunity: Fake encounters and the informalization of everyday violence in Kashmir valley. Cultural Studies 24: pp. 101132. 
Ellis, Patricia and Zafar Khan (1998) Diasporic mobilisation and the Kashmir issue in British politics. Journal of Ethnic and Migration Studies 24: pp. 471488.

- (1999a) Political allegiances and social integration: The British Kashmiris. In: Weil, Shalva (ed.): Roots and routes: Ethnicity and migration in global perspective. Jerusalem: Magnes Press: pp. 119-134.

- (1999b) Hopes and expectations: Kashmiri settlement in the United Kingdom. In: Mucha, Janusz (ed.): Dominant culture as foreign culture: Dominant groups in the eyes of minorities. Boulder, Col.: East European Monographs: pp. 97-111.

- (2002) The Kashmiri diaspora: Influences in Kashmir. In: Al-Ali, Nadje and Khalid Koser (eds.): New approaches to migration? Transnational communities and the transformation of home. London: Routledge: pp. 169-185.

Gilroy, Paul (1997) Diaspora and the detours of identity. In: Woodward, K. (ed.): Identity and difference. London: Sage: pp. 301-346.

Hutnyk, John (2006) The dialectic of "here and there": Anthropology "at home”. In: Ali, Nasreen, Virinder S. Kalra and S. Sayyid (eds.): A postcolonial people: South Asians in Britain. London: Hurst: pp. 74-90.

Kalra, Virinder S. (2000) From Textile Mills to Taxi Ranks: Experiences of Migration, Labour and Social Change. Aldershot: Ashgate.

Khan, Muzamil (2006) Devotional Islam in Kashmir and the British diaspora: The Transmission of popular religion from Mirpur to Lancashire. Unpublished PhD thesis, Dept. of Theology and Religious Studies, University of Liverpool.

Knott, Kim (2009) Becoming a "Faith Community": British Hindus, Identity, and the Politics of Representation. Journal of Religion in Europe 2: pp. 85114.

Law, John (1994) Organizing modernity. Oxford: Blackwell.

ONS (2009) Kashmiri Research Project. Available online at http://www.ons. gov.uk/census/2011-census/2011-census-questionnaire-content/question-andcontent-recommendations-for-2011/index.html (accessed 05/20/2010).

Rehman, Shams and Virinder Kalra (2006) Transnationalism from below: Initial responses of British Kashmiris to the South Asian earthquake of 2005. Contemporary South Asia 15: pp. 309-323.

Safran, William (1991) Diasporas in modern societies: Myths of homeland and return. Diaspora 1: pp. 83-99.

Saifullah Khan, Verity (1977) The Pakistanis: Mirpuri villagers at home and in Bradford. In: Watson, James L. (ed.): Between two cultures: Migrants and minorities in Britain. Oxford: Basil Blackwell: pp. 57-89. 
Sheffer, Gabriel (2003) Diaspora Politics: At Home Abroad. Cambridge: Cambridge University Press.

Sikand, Yoginder (2001) Changing course of Kashmiri struggle: From national liberation to Islamist Jihad? Economic and Political Weekly 36 (3): pp. 218227.

Sökefeld, Martin (2004) Religion or Culture? Concepts of Identity in the Alevi Diaspora. In: Kokot, Waltraud, Khachig Tölölyan and Carolin Alfonso (eds.): Diaspora, Identity and Religion: New Directions in Theory and Research. London: Routledge: pp. 133-155.

- (2005). From Colonialism to Postcolonial Colonialism: Changing Modes of Domination in the Northern Areas of Pakistan. The Journal of Asian Studies 64: pp. 939-973.

- (2006) Mobilizing in transnational space: A social movement approach to the formation of diaspora. Global Networks 6: pp. 265-284.

- (2008) Struggling for Recognition: The Alevi movement in Germany and in transnational space. New York: Berghahn.

- (2012) Secularism and the Kashmir dispute. In: Bubandt, Nils and Martijn van Beek (eds.): Varieties of secularism. Anthropological explorations of religion, politics, and the spiritual in Asia. London: Routledge: pp. 101-119.

- (2014) Diaspora und soziale Mobilisierung: Kaschmiris in England und Aleviten in Deutschland im Vergleich: In: Nieswand, Boris and Heike Drotbohm (eds.): Kultur, Gesellschaft, Migration. Die reflexive Wende in der Migrationsforschung. Wiesbaden: Springer VS: pp. 225-253.

Sökefeld, Martin and Marta Bolognani (2011) Kashmiris in Britain: A Political Project or a Social Reality? In: Bolognani, Marta and Steve M. Lyon (eds.): Pakistan and its diaspora: Multidisciplinary approaches, New York: Palgrave: pp. 111-131.

Soysal, Yasemin (2001) Citizenship and identity: Living in diasporas in post-war Europe? Ethnic and Racial Studies 23: pp. 1-15.

Tönnies, Ferdinand (1887) Gemeinschaft und Gesellschaft. Abhandlung des Communismus und des Socialismus als empirischer Culturformen. Leipzig: Fues Verlag.

Vertovec, Steven (1996) Multiculturalism, culturalism and public incorporation. Ethnic and Racial Studies 19: pp. 49-69.

- (1997) Three meanings of “diaspora” exemplified among South Asian religions. Diaspora 6 (3): pp. 277-299.

Werbner, Pnina (1989) The Ranking of Brotherhoods: the dialectics of Muslim caste among overseas Pakistanis. Contributions to Indian Sociology 23: pp. 285-315. 
- (1991) The fiction of unity in ethnic politics: Aspects of representation and the state among British Pakistanis. In: Werbner, Pnina and Muhammad Anwar (eds.): Black and ethnic leadership in Britain. London: Routledge: pp. 113-145. 


\section{About the Authors}

Bedorf, Franziska, is a sociocultural anthropologist, currently working as a post-doctoral researcher at the REAL (Resilience in East African Landscapes) innovative training network based at Uppsala University. Her research interests include migration, identity formation (ethnicity/nationalism/transnationalism), the anthropology of borders, urban ethnography, postcolonialism and organizational anthropology, with a regional focus on North and Central America, Southern Africa (Namibia) and Scandinavia. From 2010 to 2013 she was a research assistant at the Institute of Social and Cultural Anthropology at the University of Hamburg where she conducted research within the DFG-funded project "Ageing in transnational space. Processes of (re)migration between Mexico and the USA”. During that time she met Waltraut Kokot who was a full professor at the Ddepartepartment then. While doing her $\mathrm{PhD}$ on issues of migration, belonging and the life course among Mexican migrants living in Chicago, Franziska Bedorf was greatly inspired by Waltraud Kokot's work on transnationalism, migration and urban spaces.

Benovska-Sabkova, Milena, is professor of ethnology at the New Bulgarian University and at the South-West University in Blagoevgrad. Her major areas of research include anthropology of religion and the anthropology of socialism and postsocialism; anthropology of religion; minorities in Bulgaria; kinship, friendship and clientelism; mainly focused on Bulgaria, Southeast Europe and Russia. She is the author of the book "The Political Transition and Everyday Culture" (2001), founding co-editor of the journal “Ethnologia Balkanica” (1997-2002) and published more than 200 articles in academic editions abroad and home. She is also a research partner of Prof. Waltraud Kokot in her studies in Bulgaria.

Driessen, Henk, is a cultural anthropologist and Professor emeritus of Mediterranean Studies and Islam at Radboud University Nijmegen, the Netherlands. He 
has carried out fieldwork and archival research in the Mediterranean area, in particular in Spain and Morocco, and written on masculinity, religion, ritual, power, identity, borders, port cities, migration, humor, the body and pain. His publications include "On the Spanish-Moroccan Frontier" (Oxford, 1992), an edited volume with Ton Otto "Perplexities of Identification" (Aarhus, 2000), two books on the Mediterranean Sea (Amsterdam 2002, 2008), and numerous articles in scholarly journals. One of the most recent articles is on the "Hard Work of Small Talk in Ethnographic Fieldwork” (Journal of Anthropological Research, 2013) and a book in Dutch on the trauma of the Spanish Civil War (Amsterdam, 2013). His personal and professional relationship with Waltraud Kokot, which dates back to the 1980s, is based on their common interest in the ethnography of the Mediterranean area and regular meetings and workshops in Cologne, Nijmegen and Hamburg.

Dorsch, Hauke, is director of the African Music Archives in Mainz, Germany, and teaches at the Department of Anthropology and African Studies at the Johannes Gutenberg University Mainz. He held research positions and taught at Universities in Hamburg, Berlin, Bayreuth and Southampton, UK, on diaspora, trans-nationalism and migration, post-colonialism, the anthropology of globalisation, African and World Music, fieldwork methods, anthropology of Africa, etc. He also taught Anthropology and Ethnomusicology outside of academia, i.e. to teachers and students at secondary level. Furthermore he organises concerts of African musicians and other cultural events. His research experiences include fieldwork in Gambia, Senegal, Guinea-Bissau, Mali, South Africa, Mozambique, Cuba, the United States, France, Britain and Germany. He studied and obtained his M.A. and doctorate degree in Anthropology at the University of Hamburg focusing on the African diaspora, migration, popular culture, performance and music. In his academic interests, Hauke Dorsch has been very much influenced by the work and teaching of Waltraud Kokot.

Gandelsman-Trier, Mijal, is lecturer at the Department of Social and Cultural Anthropology, University of Hamburg, Germany. Her key areas of research are diaspora and migration, urban anthropology and the anthropology of space and place with a regional focus on Latin America. Waltraud Kokot's lectures and seminars were always inspiring and encouraging for Mijal Gandelsman-Trier during her studies. Her major academic and research areas were considerably influenced by Waltraud Kokot and their common interests resulted in a longstanding cooperation particularly within two research projects at the Department: "Port Cities as Areas of Transition" and "Diaspora as a Resource - transnational 
networks as cultural capital”. Both projects generated numerous outcomes in the form of publications, workshops, conferences and seminars. Beyond their academic bonds, this long lasting and trusting collaboration also became the basis for a continuing personal friendship.

Giordano, Christian, is Full Professor of Social Anthropology at the University of Fribourg, Switzerland, Doctor Honoris Causa at the University of Timisoara and permanent Guest Professor at the Universities of Bucharest, Murcia, Bydgoszcz and the University Sains Malaysia at Penang. Moreover, he teaches as regular Guest Lecturer at the Humboldt University in Berlin, at the Russian State University of Humanities in Moscow and at the University of Malaya in Kuala Lumpur. His research fields in political and urban anthropology are Southeast Europe, Mediterranean societies and Southeast Asia. Amongst the several collaborations with Waltraud Kokot is a shared interest for the study of diasporas, which is expressed in the joint edited volume "Diaspora as a Resource: Comparative Studies in Strategies, Networks and Urban Space” (edited in collaboration with Mijal Gandelsman-Trier), published in 2013.

Greiner, Clemens, is the academic coordinator of the Global South Studies Center (GSSC), a Center of Excellence at the University of Cologne (UoC). Before he joined the UoC as a post-doctoral researcher, he was trained in Social and Cultural Anthropology at the University of Hamburg. Waltraud Kokot was his main teacher during these formative years and he is greatly indebted for her continuous academic guidance and support. In his current research, he focuses on political ecology, socio-spatial relations, translocality, and the transformation of pastoralism. His regional specialisation is on Eastern and Southern Africa, where he has conducted extensive fieldwork.

Lang, Hartmut, is a retired Professor of Cultural/Social Anthropology at the University of Hamburg Germany. At present, his work comprises, among other fields, kinship and family, economic anthropology, methods in anthropology including cross cultural research, and principles of argumentation. His friendship with Waltraut Kokot goes back to the days when both studied and worked at the Department of Cultural/Social Anthropology at the University of Cologne. Their research interests have overlapped to varying degrees and they jointly published together in some fields, for example in cognitive anthropology. His greatest joy, though, were exchanges with her sharp, swift and critical mind. 
Lang, Sabine, holds a doctoral degree in cultural anthropology (Hamburg, 1990) and is an independent scholar specialized in Native American Studies. She has conducted fieldwork among the Diné (Navajo) in New Mexico, the ShoshoneBannock in Idaho, as well as among urban Native Americans, and has published widely on systems of multiple genders in indigenous North American cultures. While Sabine Lang and Waltraud Kokot never worked together in academia, they became friends a couple of years ago by a lucky coincidence, after Sabine Lang had given a guest lecture on gender and sexuality issues in one of Kokot's classes. Hence, Sabine Lang gladly accepted the invitation to contribute to the present volume, combining her expertise in Native American Studies with one of Waltraud Kokot's research interests, Jewish diasporas.

Nedin, Iliya, PhD, is associate professor at the Southwestern University "Nepfit Rilski”, Blagoevgrad, and Head of the Department of Ethnology and Balkan Studies. His main interests are ethnicity, theory and history of anthropology, religion, kinship and family.

Pauli, Julia, is Professor of Social and Cultural Anthropology at the University of Hamburg, Germany. Her main research interests are gender and kinship studies, anthropological demography, transnational migration, consumption and class formation processes. She has done extensive fieldwork in Mexico (since 1995) and Namibia (since 2003). She is author of "The Planned Child: Demographic, Economic and Social Transformations in a Mexican Community" (in German, 2000) and is currently completing a book manuscript on middle classes and life cycle rituals in Namibia. Waltraud Kokot has been a mentor, role model and colleague for Julia. Waltraud's work on migration, transnationalism, urban and cognitive anthropology continues to be a central source of inspiration and influence on Julia's research.

Pröpper, Michael, is a senior staff member and post-doctoral researcher at the Institute for Social and Cultural Anthropology of the University of Hamburg. He is the scientific coordinator of the international research project "The Future Okavango" (TFO). He studied Social and Cultural Anthropology at the University of Hamburg and was significantly supported and inspired by Waltraud Kokot during these years. In his current research, he focuses on questions of environmental anthropology, sustainability and art. His regional specialisation is on Southern Africa, where he has conducted extensive fieldwork. 
Sökefeld, Martin, is professor and head of the Dept. of Social and Cultural Anthropology of Ludwig-Maximilians-University Munich. After his PhD on ethnicity in the high mountains of Gilgit-Baltistan, Northern Pakistan, he turned to diaspora studies. From 1999 to 2005 he was assistant professor at the Dept. of Social and Cultural Anthropology of Hamburg University which at that time was headed by Waltraud Kokot. During his time in Hamburg he studied the Alevi diaspora in Germany and wrote his thesis for Habilitation. Martin Sökefeld is highly indebted to Waltraud Kokot for her continuous support and inspiration. Subsequently he became assistant professor at the University of Bern, Switzerland, were he started to study the transnational politics of the Kashmiri diaspora in the UK. Since he got his position in Munich he is focusing on Northern Pakistan again, especially on the politics of "natural” disasters.

Voutira, Eftihia, has obtained a BA in Philosophy (Honours) from the University of Chicago, an MA and a PhD from Harvard University and an MPhil and a $\mathrm{PhD}$ in Social Anthropology from the University of Cambridge. Since 2008, she is Professor in the Anthropology of Forced Migration at the Department of Balkan, Slavonic and Oriental Studies, University of Macedonia, Thessaloniki, Greece. She has done fieldwork and published extensively on the Greek diaspora in the former Soviet Union, on refugee issues and the political economy of humanitarian assistance in Africa, the Middle East and the Balkans. In 1995, while working as a Research Associate at the Refugee Studies Programme University of Oxford, she met with Waltraud and they have been in contact ever since. They collaborated in different research projects exploring common interests and institutional links, most notably on European Port Cities which included research on Salonika as one of the case-studies. Later, they also collaborated in the comparative research on Diasporas headed by the University of Hamburg under Waltraud's able supervision.

Wildner, Kathrin, is an urban anthropologist and did ethnographic fieldwork in New York City, Mexico City, Istanbul, Bogotá and other urban agglomerations. At the Department of Social and Cultural Anthropology at Hamburg University Waltraud Kokot encouraged and supervised her doctoral thesis Thesis "Zócalo Ethnographie eines Platzes in Mexiko Stadt”. Meanwhile an experienced urban researcher, Kathrin Wildner teaches, publishes and participates in transdisciplinary projects and international exhibitions. She is a founding member of metroZones - Center for Urban Affairs and was the coordinator of arts and sciences within the interdisciplinary research and art project "The Global Players Congress: Faith in the City” (2010-2014). Between 2013 and 2015 she was Visiting 
Professor at the Master Program "Spatial Strategies" (Raumstrategien) at the Art Academy Weißensee, Berlin. Since 2012 she is professor for Cultural Theory and Practice at the HafenCity University in Hamburg.

Wonneberger, Astrid, is researcher and lecturer for family science at the University of Applied Sciences (HAW) Hamburg and private lecturer (PD) for cultural and social anthropology at the University of Hamburg. Her personal and professional friendship to Waltraud Kokot dates back to her time as graduate student. Waltraud Kokot not only became her doctoral supervisor, but also influenced her significantly in developing her major academic interests, which include the anthropology of kinship and family, urban anthropology, studies of ethnicity, migration and diaspora. They have also cooperated in numerous teaching and research projects, such as Denkwerk Ethnologie, European Port Cities as Areas of Transition and Ethnographie eines Straßenzuges auf St Pauli at the Department of Social and Cultural Anthropology at the University of Hamburg. 